\title{
Validation of Turkish Version of Newest Vital Sign Scale to Assess Health Literacy
}

\section{Sağlık Okuryazarlığını Değerlendirmede NVS Ölçeği Türkçe Geçerliliği}

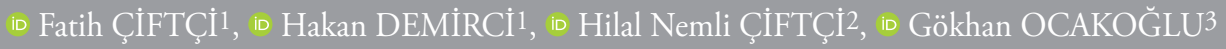

1Bursa Yüksek İhtisas Training and Research Hospital, Clinic of Family Medicine, Bursa, Turkey

2Bursa Yüksek İhtisas Training and Research Hospital, Clinic of Internal Diseases, Bursa, Turkey

3Uludağ University Faculty of Medicine, Department of Biostatistics, Bursa, Turkey

\section{ABSTRACT}

Objective: The aim of the study was to check Turkish validation of the Newest Vital Sign (NVS) scale.

Methods: The participants were composed of the patients who were registered in a Family Health Center located in Bursa between September 2016 and February 2017. The subjects selected by random sampling method and they were invited to the study. The research was performed by applying survey with the face to face method to the participants.

Results: Turkish version of the NVS scale is a valid tool to assess health literacy. Cronbach alpha coefficient was calculated as 0.720 for NVS scale. Receiver Operating Characteristic analysis revealed a cut-off point for the NVS scale which was 4. According to the NVS scale, $57.9 \%$ of the participants had an adequate health literacy level.

Conclusion: This sample was found to be adequate for validation analysis of NVS scale. NVS is a reliable and valid tool to evaluate health literacy among Turkish population and the cut-off point for the scale is 4 . Health literacy is inadequate for less than half of the people living in our region.

Keywords: Health literacy, newest vital sign, reliability, validation

\section{ÖZ}

Amaç: Bu çalışmanın amacı En Yeni Yaşamsal Bulgu (EYYB) ölçeğinin Türkçe geçerliliğinin araştırılmasıdır.

Yöntemler: Katılımcılar, Eylül 2016-Şubat 2017 tarihleri arasında Bursa'da bulunan bir aile sağlığı merkezine kayıtlı hastalardan oluşuyordu. Rastgele örnekleme yöntemi ile seçilen kişiler çalışmaya davet edildi. Araştırma, katılımcılara yüz yüze yöntemi ile anket uygulanarak gerçekleştirildi.

Bulgular: EYYB ölçeğinin Türkçe versiyonu, sağlık okuryazarlığını değerlendirmek için geçerli bir araçtır. Cronbach alfa katsayısı EYYB için 0,720 olarak hesaplandı. Alıcı işletim karakteristiği analizi, EYYB ölçeği için 4 olan bir kesme noktası ortaya çıardı. EYYB ölçeğine göre, katılımcıların \%57,9'u yeterli sağlık okuryazarlığı seviyesine sahipti.

Sonuç: $\mathrm{Bu}$ örneklem EYYB ölçeğinin geçerliliğini araştırmak için yeterlidir. EYYB, Türk nüfusu arasında sağlık okuryazarlı̆̆ını değerlendirmek için güvenilir ve geçerli bir araçtır ve ölçeğin kesme noktası 4’tür. Sağlık okuryazarlığı bölgemizde yaşayan insanların yarısından fazlası için yeterlidir.

Anahtar Sözcükler: Sağlık okuryazarlığı, En Yeni Yaşamsal Bulgu ölçeği, güvenirlik, geçerlilik
Address for Correspondence: Hakan DEMiRCi, Bursa Yüksek ihtisas Training and Research Hospital, Clinic of Family Medicine, Bursa, Turkey

E-mail: drhakandemirci@hotmail.com ORCID ID: orcid.org/0000-0003-0434-4807
Received: 10.01 .2020

Accepted: 11.06 .2020

Cite this article as: Çiftçi F, Demirci H, Nemli Çiftçi H, Ocakoğlu G. Validation of Turkish Version of Newest Vital Sign Scale to Assess Health Literacy. Bezmialem Science 2021;9(2):219-25. 


\section{Introduction}

World Health Organization defines health literacy (HL) as "The cognitive and social skills that determine the motivation and ability of individuals to gain access to understand and use information in ways that promote and maintain good health" (1). According to The European HL Survey Consortium definition, HL has a scope that evaluates the knowledge, motivation, and sufficiency of individuals about benefiting from health services, preventing diseases, and improving health in order to improve the quality of life (2). HL can also be defined as the individual's capacity of acquisition, interpretation, and comprehension of basic health information and services in terms of protecting, developing, and curing the individual's health $(3,4)$.

HL has gained a significant importance with respect to the past. Recently, reasons such as increasing importance of preventive health services, consideration of individual health service, generally low level of HL, insufficient reflection of healthrelated issues to the society, and increase in health expenses, have raised the importance of HL (5-7). Individuals with low level of HL cause some unintended consequences, such as high hospital charges, long duration of hospital stay, inappropriate use of emergency services, and inappropriate increase in health expenses (8-10).

Assessing HL is of particular importance for public health. Newest Vital Sign (NVS) scale, consisting of 8 questions, is an easy-to-implement and easy-to-interpret instrument to assess HL. NVS was studied by Ozdemir et al. (11); however, the validity of the study could not be performed because of the absence of equivalent Turkish questionnaire that could match at that time. This study aimed to check the Turkish validation of the NVS scale.

\section{Methods}

Target population of the study is composed of patients between ages 18-65 years, who are registered to the Family Health Center in Bursa City between September 2016 and February 2017. During the period when the research was conducted, 12,468 individuals were registered to the Family Health Center and 8,164 of them were between ages 18-65 years. A total of 400 volunteers were selected from the patients' list by random sampling method and were invited to the study. The research was performed using a face-to-face survey method to all participants. This study was approved by the Bursa Yüksek İhtisas Training and Research Hospital, Ethics Committee for Clinical Investigations. A written informed consent was obtained from all participants.

A survey form interrogating the socio-demographic features and NVS scale and the Turkish translation of the European HL Survey Questionnaire (HLS-EU-Q) were used to measure the HL level of patients.

The Turkish version of the HLS-EU-Q was validated by Abacigil et al. (12). The scale is composed of 47 questions and each of these 47 questions is graded in a scale of $1-4$ points (1: very difficult, 2: difficult, 3: easy, 4: very easy). HL about the health care service, prevention from diseases, and promotion of health is analyzed within the matrix of the following issues: access to the information, comprehension, evaluation, and implementation of the information.

NVS scale was studied by Ozdemir et al. (11) in 2010. Its validation could not be achieved at that time due to the absence of a scale to compare results. In NVS scale, patients are given a copy of a food label and asked six questions related to the label. The first four questions among them require calculation capability and the last two questions do not require numerical skills. Each correct answer given is graded as 1 point and the HL level of the individual is determined according to the total score he/she gets. Retest for NVS scale was performed 15 days after the first interview.

\section{Statistical Analysis}

Normal distribution suitability of variables was analyzed with Shapiro-Wilk test. Variables were expressed in mean, standard deviation, or median (minimum-maximum) values. MannWhitney $U$ test between two groups was used accordingly to test the normality of results, and Kruskal-Wallis test was used in case with more than two groups. Following Kruskal-Wallis test, Dunn-Bonferroni approach was used in order to determine the group or groups that were different, and multiple comparison procedures were applied. Receiver Operating Characteristic (ROC) analysis was made in order for the NVS scale to predict HL, and related cut-off point was calculated. The construct validity of NVS scale was investigated using explanatory factor analysis. While internal consistency of scales was analyzed with Cronbach's alpha and Kuder-Richardson 20 (KR-20) coefficients, relationships between scores of the scales were analyzed with correlation analysis, and Spearman correlation coefficient was calculated. The Statistical Package for the Social Sciences (IBM Corp. Released 2012. IBM SPSS Statistics for Windows, Version 21.0. Armonk, NY: IBM Corp.) and MedCalc Statistical Software trialversion 16.4.3 (MedCalc Software BVBA, Ostend, Belgium; https://www.medcalc.org; 2016) programs were used for statistical analysis, and $\mathrm{p}<0.05$ was accepted as statistically significant.

\section{Results}

A total of 376 participants agreed to enroll in the study (response rate was $94 \%$ ). The mean age of participants was $37.17 \pm 11.60$ years (range between 18-65 years). General characteristics of participants are shown in Table 1.

The distribution of mean points for HLS-EU-Q and NVS scale are presented in Table 2. The mean HLS-EU-Q score was 33.24 \pm 7.45, whereas the mean NVS scale score was 3.76 \pm 1.83 .

The distribution of HL status classified by HLS-EU-Q and NVS is shown in Table 3. According to HLS-EU-Q, $45.2 \%$ of participants had adequate HL level, whereas $57.9 \%$ according to the NVS scale. Comparisons among the gender groups revealed that NVS scale scores of male participants were higher than those 
Table 1. General characteristics of participants

\begin{tabular}{|c|c|c|}
\hline & $\begin{array}{l}\text { The number of } \\
\text { participants (n) }\end{array}$ & Percent (\%) \\
\hline \multicolumn{3}{|l|}{ Gender } \\
\hline Female & 202 & (53.72\%) \\
\hline Male & 174 & $(46.28 \%)$ \\
\hline \multicolumn{3}{|l|}{ Education } \\
\hline Literate & 91 & $(24.20 \%)$ \\
\hline Secondary school & 51 & $(13.56 \%)$ \\
\hline High school & 100 & (26.50\%) \\
\hline University & 134 & (35.64\%) \\
\hline \multicolumn{3}{|l|}{ Economic status } \\
\hline Low & 17 & $(4.52 \%)$ \\
\hline Moderate & 238 & $(63.30 \%)$ \\
\hline High & 121 & $(32.18 \%)$ \\
\hline \multicolumn{3}{|l|}{ Occupation } \\
\hline House wife & 122 & $(32.45 \%)$ \\
\hline Student & 28 & $(7.45 \%)$ \\
\hline Worker & 76 & (20.21\%) \\
\hline Self-employee & 8 & $(2.13 \%)$ \\
\hline Professional & 67 & $(17.82 \%)$ \\
\hline Retired & 32 & (8.51\%) \\
\hline Others & 43 & $(11.44 \%)$ \\
\hline \multicolumn{3}{|l|}{ Marital status } \\
\hline Married & 284 & $(75.50 \%)$ \\
\hline Single & 92 & $(24.5 \%)$ \\
\hline
\end{tabular}

of the female $(\mathrm{p}=0.023)$. Period of study of men was statistically significantly better than that of women $(\mathrm{p}<0.001)$.

Same directional significant relationship was found between NVS scale score and Health service, Disease prevention HL, Health protection HL, General HL scale scores $(\mathrm{p}<0.001$, $\mathrm{p}<0.001, \mathrm{p}<0.001, \mathrm{p}<0.001$, respectively) (Table 4).

HLS-EU-Q scores were achieved by classifying the answers of participants to each question as "very difficult or difficult" or "very easy and easy," as shown in Table 5. Participants of the current study are found to be more successful in terms of health care and information comprehension compared to other studies reflecting Europe and countrywide of Turkey. On the contrary, our participants express their difficulties in periodic examinations and adult vaccination issues.

In order to predict the sufficient and perfect HL for NVS scale, cut-off point value is found as "4," and the field below the ROC curve including this cut-off point is found as 0.688 ( $\mathrm{p}$ value: $\mathrm{p}<0.001$ ) (Figure 1).

\section{HLS-EU-Q Reliability Analysis}

In the reliability analysis of scales, Cronbach's alpha coefficient is used for general HLS-EU-Q and its sub-scales, and KuderRichardson 20 (KR-20) coefficient is used for NVS scale. When coefficients are analyzed, reliability of the HLS-EU-Q is found perfect for health service HL $(\alpha=0.904)$, health protection

Table 2. Distribution of mean points for HLS-EU-Q and NVS scale

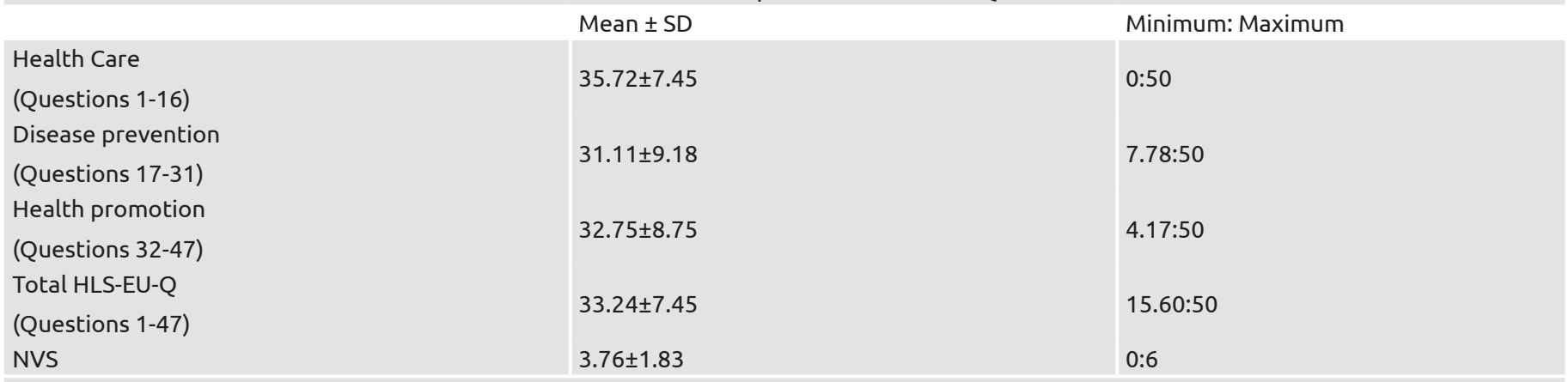

HLS-EU-Q: The European Health Literacy Survey Questionnaire; NVS: Newest Vital Sign, SD: Standard deviation

Table 3. Distribution of Health Literacy Status classified by HLS-EU-Q and NVS scale

\begin{tabular}{|c|c|c|c|c|c|}
\hline & & NVS & & & \\
\hline & & $\begin{array}{l}0-1 \\
\text { (Limited HL) }\end{array}$ & $\begin{array}{l}2-3 \\
\text { (Possibly limited HL) }\end{array}$ & $\begin{array}{l}\text { 4-6 } \\
\text { (Adequate } \mathrm{HL} \text { ) }\end{array}$ & Total \\
\hline & $\begin{array}{l}\text { Inadequate } \mathrm{HL} \\
(0-25)\end{array}$ & 14 & 18 & 15 & 47 \\
\hline & Problematic HL (>25-33) & 30 & 47 & 82 & 159 \\
\hline HLS-EU-Q & $\begin{array}{l}\text { Sufficient HL } \\
(>33-42)\end{array}$ & 7 & 31 & 75 & 113 \\
\hline & $\begin{array}{l}\text { Excellent HL } \\
(>42-50)\end{array}$ & 4 & 7 & 46 & 57 \\
\hline & Total & 55 & 103 & 218 & 376 \\
\hline
\end{tabular}


$(\alpha=0.905)$, and general ( $\alpha=0.953)$; good for disease prevention sub-index $(\alpha=0.895)$.

\section{NVS Scale Internal Consistency}

The internal consistency of the NVS scale for an individual was examined using Cronbach's alpha coefficient. From the overall assessment of the scale, Cronbach's alpha coefficient was calculated as 0.720 . When Cronbach's alpha coefficient is considered, it is seen that the NVS scale is an acceptable measurement tool in terms of internal consistency.

\section{NVS Scale Construct Validity}

Explanatory factor analysis (EFA) has been applied to determine the structure validity of the NVS scale. Prior to EFA, the Kaiser Meyer-Olkin (KMO) sample proficiency test and Bartlett's globality test were performed to assess sample adequacy and factor correlation matrix appropriateness. The KMO value was 0.76 and the Bartlett test result was $\chi 2=4284.7$ and statistically significant $(\mathrm{p}<0.001)$. The factor analysis is applicable if the KMO test result is above 0.50 , and the Bartlett test is significant so that the correlation matrix of the substances found in the

Table 4. Relationship between HLS-EU-Q and NVS scale

\section{NVS}

$r_{s}$

\begin{tabular}{l|l|l}
\hline $\begin{array}{l}\text { Health Care } \\
\text { (Questions 1-16) }\end{array}$ & 0.385 & $<0.001$ \\
$\begin{array}{l}\text { Disease Prevention } \\
\text { (Questions 17-31) }\end{array}$ & 0.328 & $<0.001$ \\
$\begin{array}{l}\text { Health Promotion } \\
\text { (Questions 32-47) }\end{array}$ & 0.322 & $<0.001$ \\
$\begin{array}{l}\text { Total HLS-EU-Q } \\
\text { (Questions 1-47) }\end{array}$ & 0.388 & $<0.001$
\end{tabular}

HLS-EU-Q: The European Health Literacy Survey Questionnaire; NVS: Newest Vital Sign; Spearman correlation coefficients were given as (rs) and p values

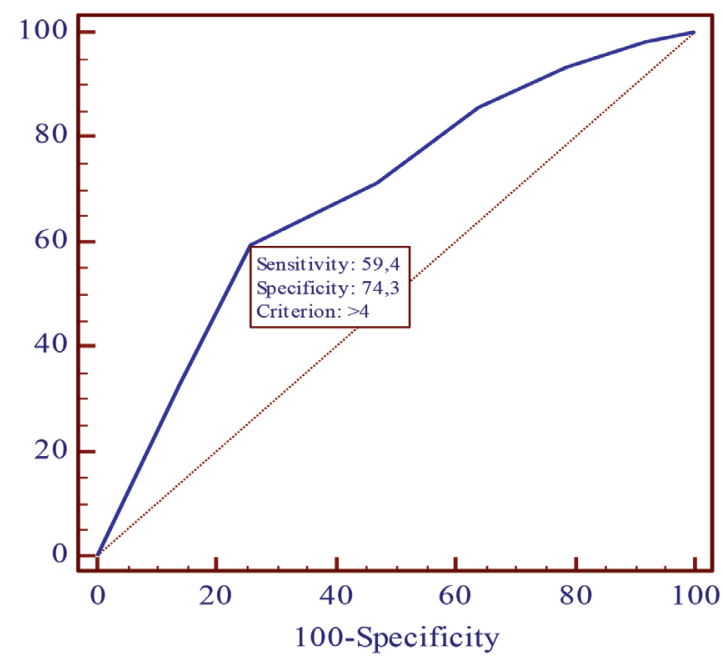

Figure 1. ROC curve for Newest vital sign scale scale is suitable for factor analysis (13). Polychoric correlation matrix was used in factor analysis due to the fact that responses to substances forming the NVS scale are binary valued (true/false). Parallel analysis has been used to determine the number of factors in EFA (14). Principle Component Analysis was used as a factor extraction method and the Varimax rotation technique, which is one of the most commonly used upright rotation techniques, was used to provide independence and clarity in interpretation during the analysis. The Eigen values of 6 items was found to be above 1 and grouped under factor 1, which explained $55 \%$ of the total variance (Table 6).

\section{NVS Scale Test-retest Reliability}

The consistency of the scale and the correlation of the test-retest values were assessed. When the test-retest reliability of the NVS scale was examined, a correlation between test and retest scores $\left(r_{s}=0.36 ; p=0.031\right)$ was found.

\section{NVS Scale Criterion/Construct Validity}

The relationship between the NVS scale and equivalent scale (HLS-EU) was investigated in this study. A significant relationship was found between the calculated NVS scale scores and HLS-EU-Q scores $(\mathrm{p}<0.001)$.

\section{Discussion}

This sample was found to be adequate for validation analysis of the NVS scale. We found that the NVS scale was a reliable and valid tool to evaluate $\mathrm{HL}$ among the Turkish population, with the cut-off point of 4. According to the NVS scale, $57.9 \%$ of participants had adequate HL level. Participants express their difficulties in judging the information on health risks in the media as reliable and issues related to adult vaccination.

According to the research results, a significant positive relationship was seen between the results achieved from NVS scale and HLSEU-Q and its sub-groups. At the same time, internal validity of these two scales is provided in our study group. NVS scale cut-off point for the Turkish society was determined as 2 in a previous study by Ozdemir et al. (11); however, according to the present study, suggested cut-off point for NVS scale to diagnose adequate HL was 4 .

Studies show that the level of HL varies between communities. A survey of eight European countries found sufficient HL in $36 \%$ of the population and excellent HL in $16.5 \%$. In this study, Netherlands was found to be the best country with sufficient/ excellent HL in total (2). A study held in primary care in the United States found that $1 / 3$ of the population belongs to the limited HL group (15). In a review, limited HL in five countries in the Southeast Asian region was reported as $55.3 \%$ on average (16). Values we identified in our study are similar to these values. Comparisons with non-European countries are open to debate as different scales are used.

According to the HLS-EU scale results, participants had the most difficulty with the subject "to judge if the information on health risks in the media is reliable." Media in our country and 
Table 5. Comparisons of answers of the Health Literacy European Union Questionnaire with the existing literature

Difficult and Fairly Difficult (\%)

Questions

Europe Turkey Results of the

Q.1 Finding information about symptoms of illnesses that concern you.

present study

Q.2 Finding information on treatments for illnesses that concern you.

Q.3 Finding out what to do in case of a medical emergency.

Q.4 Finding out where to get professional help when you are ill.

Q.5 Understanding what your doctor says to you.

Q.6 Understanding the leaflets that come with your medicine.

Q.7 Understanding what to do in a medical emergency.

Q.8 Understanding your doctor's or pharmacist's instruction on how to take a prescribed medicine.

Q.9 Judging how information from your doctor applies to you.

Q.10 Judging the advantages and disadvantages of different treatment options.

Q.11 Judging when you may need to get a second opinion from another doctor.

Q.12 Judging if illness information from the media is reliable.

Q.13 Using information the doctor gives you to make decisions about your illness.

Q.14 Following medication instructions.

Q.15 Calling an ambulance in an emergency.

Q.16 Following instructions from your doctor or pharmacist.

\begin{tabular}{l|l|l}
22.8 & 32.2 & 15.16 \\
26.9 & 32.3 & 15.43
\end{tabular}

\begin{tabular}{l|l|l}
21.8 & 39.1 & 13.30
\end{tabular}

\begin{tabular}{l|l|l}
11.9 & 19.4 & 5.32
\end{tabular}

\begin{tabular}{l|l|l}
15.3 & 22.5 & 7.18
\end{tabular}

\begin{tabular}{l|l|l}
28.0 & 42.9 & 11.70
\end{tabular}

\begin{tabular}{l|l|l}
21.7 & 42.0 & 21.54
\end{tabular}

\begin{tabular}{l|l|l|}
6.5 & 11.9 & 4.26
\end{tabular}

\begin{tabular}{l|l|l}
18.0 & 19.6 & 9.31
\end{tabular}

\begin{tabular}{l|l|l|}
42.6 & 43.1 & 34.04
\end{tabular}

\begin{tabular}{l|l|l|}
38.6 & 32.3 & 30.32
\end{tabular}

\begin{tabular}{l|l|l|}
49.7 & 48.2 & 47.87
\end{tabular}

\begin{tabular}{|l|l|l|}
23.1 & 28.4 & 16.49
\end{tabular}

\begin{tabular}{l|l|l|}
6.8 & 11.9 & 8.24
\end{tabular}

\begin{tabular}{l|l|l}
8.8 & 13.0 & 3.46
\end{tabular}

\begin{tabular}{l|l|l}
5.6 & 8.7 & 2.39
\end{tabular}

Q.17 Finding information about how to manage unhealthy behavior such as smoking, low physical activity, and excessive drinking.

Q.18 Finding information on how to manage mental health problems like stress or depression.

Q.19 Finding information about vaccinations and health screenings that you should have.

33.5

41.1

21.28

Q.20 Finding information on how to prevent or manage conditions like being overweight, high blood

24.0

38.4

22.61

pressure, or high cholesterol.

18.

Q.21 Finding health warnings about behavior such as smoking, low physical activity, and excessive drinking.

Q.22 Understanding the need for vaccinations.

10.3

34.1

20.21

Q.23 Understanding the need for health screenings.

Q.24 Judging the reliability of health warnings, such as smoking, low physical activity, and excessive drinking.

Q.25 Understanding the need to go to a doctor for a check-up.

Q.26 Understanding the necessary vaccinations.

Q.27 Understanding the necessary health screenings.

Q.28 Understanding the reliability of information on health risks from the media.

16.3

Q.30 Deciding how you can protect yourself from illness based on advice from family and friends.

Q.31 Deciding how you can protect yourself from illness based on information from the media.

Q.34 Finding information on how your neighborhood could be more health-friendly.

Q.35 Finding out about political changes that may affect health. 


\begin{tabular}{|c|c|c|c|c|c|c|c|}
\hline \multicolumn{8}{|c|}{ Table 6. NVS scale construct validity } \\
\hline \multirow{2}{*}{ Factor 1} & Question & 1 & 2 & 3 & 4 & 5 & 6 \\
\hline & Factor load & 0.53 & 0.66 & 0.77 & 0.73 & 0.84 & 0.87 \\
\hline \multirow{3}{*}{$\begin{array}{l}\text { Eigen value } \\
\text { \%Variance }\end{array}$} & 3.29 & & & & & & \\
\hline & $55 \%$ & & & & & & \\
\hline & $\begin{array}{l}\text { Kaiser-Mey } \\
\text { Bartlett Tes }\end{array}$ & $\begin{array}{l}\text { t: } 0.76 \\
<0.001\end{array}$ & & & & & \\
\hline
\end{tabular}

across the world may be at odds with evidence-based medicine (17-19). For example, parents who are misguided about neonatal vaccinations in Turkey do not vaccinate their children, and as a result, the incidence of preventable infectious diseases has recently increased $(20,21)$. In another example, the media inculcates pregnant women not to have oral glucose tolerance test, thus placing the mother and children at risk $(22,23)$. The fact that the reliability of health information in the media is the most challenging topic in the HL survey suggests that the scale can be used to identify health-related issues. Another issue that participants feel themselves insufficient is adult vaccinations. Adult vaccinations protect the individual's health as well prevention of labor loss. Pneumonia and influenza vaccines are recommended for patients with asthma, diabetes mellitus, and coronary failure, and in individuals over 65 years old, thus the social security institution covers some part of these vaccinations $(24,25)$. Family physicians should inform their patients about vaccination in case of the existence of these diseases and other indications.

\section{Study Limitations}

One of the limitations of the study is that this is a mono-center study. This study that is performed in Bursa Yuksek İhtisas Training and Research Hospital Baglaralti Family Health Center reflects the results of this region and these results cannot be generalized. Only participants who could visit the Family Health Center are included in our study. The situation may be different in advanced patients who get home care services. HL status of patients who cannot visit the polyclinic may affect the total scores.

\section{Conclusion}

NVS scale is a reliable and valid tool to evaluate HL among the Turkish population, having the cut-off point of 4 . HL is inadequate for less than half of the people living in our region. Patients should be more informed about health risks and issues related to adult vaccination through the media.

Acknowledgments: Authors thank Mrs. Nazlı Demirci (Philologist) for her contribution to the study.

\section{Ethics}

Ethics Committee Approval: Bursa Yüksek İhtisas Training and Research Hospital, Ethics Committee for Clinical Investigations approved the study (10.08.2016 2011-KAEK-25 2016/14-11).
Informed Consent: A written informed consent was obtained from the participants.

Peer-review: Externally peer reviewed.

\section{Authorship Contributions}

Concept: H.D., Design: F.Ç., H.D., Data Collection or Processing: F.Ç., H.N.Ç., Analysis or Interpretation: G.O., F.Ç., H.D., Literature Search: F.Ç., H.D., H.N.Ç., Writing: F.Ç., H.D., H.N.Ç. G.O.

Conflict of Interest: No conflict of interest was declared by the authors.

Financial Disclosure: The authors declared that this study received no financial support.

\section{References}

1. Berkman ND, Davis TC, McCormack L. Health literacy: what is it? J Health Commun 2010;15:9-19.

2. Sørensen K, Pelikan JM, Röthlin F, Ganahl K, Slonska Z, Doyle G, et al. Health literacy in Europe: comparative results of the European health literacy survey (HLS-EU). Eur J Public Health 2015;25:10538.

3. Baker DW. The meaning and the measure of health literacy. J Gen Intern Med 2006;21:878-83.

4. Sørensen K, Van den Broucke S, Fullam J, Doyle G, Pelikan J, Slonska Z, et al. Health literacy and public health: a systematic review and integration of definitions and models. BMC Public Health 2012;12:80.

5. Nutbeam D. Health literacy as a public health goal: a challenge for contemporary health education and communication strategies into the 21st century. Health promotion international 2000;15:259-67.

6. Berkman ND, Sheridan SL, Donahue KE, Halpern DJ, Crotty K. Low health literacy and health outcomes: an updated systematic review. Ann Intern Med 2011;155:97-107.

7. Schulz PJ, Nakamoto K. Health literacy and patient empowerment in health communication: the importance of separating conjoined twins. Patient Educ Couns 2013;90:4-11.

8. Baker DW, Parker RM, Williams MV, Clark WS. Health literacy and the risk of hospital admission. J Gen Intern Med 1998;13:791-8.

9. Kripalani S, Jackson AT, Schnipper JL, Coleman EA. Promoting effective transitions of care at hospital discharge: a review of key issues for hospitalists. J Hosp Med 2007;2:314-23. 
10. Weiss BD, Palmer R. Relationship between health care costs and very low literacy skills in a medically needy and indigent Medicaid population. J Am Board Fam Pract 2004;17:44-7.

11. Ozdemir H, Alper Z, Uncu Y, Bilgel N. Health literacy among adults: a study from Turkey. Health Educ Res 2010;25:464-77.

12. Abacigil F, Harlak H, Okyay P, Kiraz DE, Gursoy Turan S, Saruhan $\mathrm{G}$, et al. Validity and reliability of the Turkish version of the European Health Literacy Survey Questionnaire. Health Promot Int 2019;34:658-67.

13. Tavsancil E. Measurement of attitudes and SPSS function analysis. Ankara: Nobel Yayincilik.; 2002.

14. Timmerman ME, Lorenzo-Seva U. Dimensionality assessment of ordered polytomous items with parallel analysis. Psychol Methods 2011;16:209-20.

15. Hersh L, Salzman B, Snyderman D. Health Literacy in Primary Care Practice. Am Fam Physician 2015;92:118-24.

16. Rajah R, Hassali MAA, Murugiah MK. A systematic review of the prevalence of limited health literacy in Southeast Asian countries. Public Health 2019;167:8-15.

17. Chapman JR, Wiechert K, Wang JC. Evidence-Based Medicine, Media, and Manipulation. Global Spine J 2018;8:437-9.

18. Foran T. Contraception and the media: lessons past, present and future. Eur J Contracept Reprod Health Care 2019;24:80-2.
19. Vitek K, Ward LM. Risky, Dramatic, and Unrealistic: Reality Television Portrayals of Pregnancy and Childbirth and their Effects on Women's Fear and Self-Efficacy. Health Commun 2019;34:128995.

20. Gür E. Vaccine hesitancy - vaccine refusal. Turk Pediatri Ars 2019;54:1-2.

21. Topçu S, Almış H, Başkan S, Turgut M, Orhon FŞ, Ulukol B. Evaluation of Childhood Vaccine Refusal and Hesitancy Intentions in Turkey. Indian J Pediatr 2019;86:38-43.

22. Hocaoglu M, Turgut A, Guzin K, Yardimci OD, Gunay T, Bor $\mathrm{ED}$, et al. Why some pregnant women refuse glucose challenge test? Turkish pregnant women's perspectives for gestational diabetes mellitus screening. North Clin Istanb 2018;6:7-12.

23. Yaprak M, Gümüştakım RS, Tok A, Doganer A. Gebelerde Oral Glukoz Tolerans Testi Farkındalığının Tespiti. Ankara Medical Journal 2019;19:635-47.

24. Guclu OA, Demirci H, Ocakoglu G, Guclu Y, Uzaslan E, Karadag M. Relationship of pneumococcal and influenza vaccination frequency with health literacy in the rural population in Turkey. Vaccine 2019;37:6617-23.

25. Bozkurt H, Demirci H. Health literacy among older persons in Turkey. Aging Male 2019;22:272-7. 